\title{
Multilevel Analysis on the Contextual Effect of Posyandu on Healthy Prenatal Behavior Among Pregnant Women in Bengkayang, West Kalimantan
}

\author{
Dayang Fitri Murdikawati'), Uki Retno Budihastuti²), \\ Yulia Lanti Retno Dewi3) \\ 1)Masters Program in Public Health, Universitas Sebelas Maret \\ 2)Department of Obstetrics and Gynecology, Dr. Moewardi Hospital \\ 3)Faculty of Medicine, Universitas Sebelas Maret, Surakarta
}

\begin{abstract}
Background: Evidence suggests that prenatal care, healthy behaviors such as exercise and nutrition, general stress level, and routine blood pressure examination, are associated with fetal and maternal health. However, there is a lack of studies on factors affecting these healthy prenatal behaviors in Indonesia. This study aimed to determine the contextual effect of posyandu on healthy prenatal behavior among pregnant women in Bengkayang, West Kalimantan

Subjects and Method: A cross-sectional study was conducted at 25 integrated health posts (posyandu) in Bengkayang, West Kalimantan, from November to December 2018. A sample of 200 pregnant women was selected by simple random sampling. The dependent variable was healthy prenatal behavior. The independent variables were maternal education, family income, knowledge, health personnel support, family support, community leader support, and distance to posyandu. The data were collected by questionnaire and analyzed by multilevel logistic regression.

Results: Healthy prenatal behavior was affected by maternal education $(b=4.64 ; 95 \% \mathrm{CI}=2.05$ to 7.23; $\mathrm{p}<0.001)$, family income $(\mathrm{b}=3.26 ; 95 \% \mathrm{CI}=1.15$ to $5.37 ; \mathrm{p}=0.002)$, knowledge $(\mathrm{b}=2.83 ; 95 \%$ $\mathrm{CI}=0.90$ to $4.47 ; \mathrm{p}=0.004)$, family support $(\mathrm{b}=2.69 ; 95 \% \mathrm{CI}=0.70$ to $4.69 ; \mathrm{p}=0.008)$, community leader support $(b=3.01 ; 95 \% \mathrm{CI}=1.05$ to $4.96 ; \mathrm{p}=0.003)$, health personnel support $(\mathrm{b}=3.74$; $95 \% \mathrm{CI}=1.44$ to $6.04 ; \mathrm{p}=0.001)$, and distance to posyandu $(\mathrm{b}=-3.51 ; 95 \% \mathrm{CI}=-5.50$ to $-1.52 ; \mathrm{p}=$ o.001). Posyandu had strong contextual effect on healthy prenatal behavior with ICC $=74 \%$.

Conclusion: Healthy prenatal behavior is affected by maternal education, family income, knowledge, family support, community leader support, health personnel support, and distance to posyandu. Posyandu has strong contextual effect on healthy prenatal behavior.
\end{abstract}

Keywords: healthy prenatal behavior, prenatal, path analysis

\section{Correspondence:}

Dayang Fitri Murdikawati. Masters Program in Public Health, Universitas Sebelas Maret, Jl. Ir. Sutami 36A, Surakarta 57126, Central Java, Indonesia. Email: DayangFM@gmail.com.

Mobile: 08999988880.

\section{BACKGROUND}

$\overline{\text { Prenatal period is a very important period }}$ in pregnancy that determines individual development in subsequent periods and during this period the mother experiences different physiological and psychological changes (Littletan, 2012). Healthy behavior during prenatal period is very important to do, to avoid complications and deaths for both mother and fetus (Parsa, 2018). In addition, given the important role of mothers in the family, maternal mortality can also lead to further poverty, higher child mortality, malnutrition, and children dropping out of school (Washio, Yukiko \& Mara Humphreys, 2018).

Mother's healthy behavior is formed by three factors, namely predisposing factors, supporting factors, and driving factors (Purwoastuti \& Walyani, 2015). 
Predisposing factors are formed in knowledge. Without one's knowledge, there is no basis for making decisions and determining actions against problems (Wibisono \& Dewi, 2009). Supporting factors are manifested in the physical environment, available or unavailability of facilities or health facilities and access to health facilities that provide health services, such as the availability of posyandu and affordability of prenatal mothers to the posyandu. the behavior of health personnel, family support and community leaders (Purwoastuti \& Walyani, 2015). Health power is an important need to determine the condition of pregnacy (Irianto, 2014) and families are needed to support mothers to be more confident so as to reduce anxiety in pregnancy and community leaders also plays an important role as one of the elements of social capital that can affect prenatal mothers to behave in a healthy manner so that mothers have readiness in facing pregnancy and childbirth later (Subaris, 2016).

Posyandu or integrated service post is one form of community-sourced health efforts that are managed and organized from, by, and for the community assisted by health personnel in a Puskesmas work area, to empower the community and provide convenience to the community in obtaining basic health services, especially to improve the healthy behavior of pregnant women so as to accelerate the reduction of maternal and infant mortality, where the program can be implemented in hamlet halls, urban halls, and other places that are easily accessible by the community (Ismawati, 2010).

$\frac{\text { SUBJECTS AND METHOD }}{\text { 1. Study Design }}$
This was an analytic observational study with
a cross sectional design. The study was

conducted in 25 Posyandu in Bengkayang Regency in November 2018 - December 2018.

\section{Population and Sample}

The source population, in this study was 200 prenatal mothers in Bengkayang Regency, West Kalimantan. The sampling used simple random sampling technique.

\section{Study Variables}

The dependent variable was prenatal healthy behavior. The independent variables were maternal education, maternal knowledge, family income, health personnel support, family support, support from community leaders, distance to posyandu.

\section{Operational Definition of Variables}

The definition of prenatal healthy behavior is the act of pregnant women to perform healthy behaviors in preventing maternal and fetal complications / deaths during masaprenatal. Data collection was done using questionnaires. The measurement scale used is continuous data with a measurement of $\mathrm{o}=$ unhealthy behavior (score $<10$ ) and $1=$ healthy behavior (score $\geq 10$ ).

The operational definition of maternal education is the last formal education level that is taken based on the last diploma owned. Data collection was done using a questionnaire sheet. The measurement scale used is categorical data with the results of measuring $\mathrm{o}=$ low education (elementary and junior high school); $1=$ higher education (high school and college).

The definition of operational family income is a condition that describes the income of a husband and wife obtained through work calculated every month. Data collection was used using questionnaires. The measurement scale used was in the form of continuous data with a measure of $\mathrm{o}=$ low $(<$ minimum wage $) ; 1=$ high $(\geq$ minimum wage).

Operational definition of mother's knowledge about prenatal healthy behavior is the thinking of pregnant women about 
healthy behaviors of the prenatal as a result of information or messages received. Data collection was done using a questionnaire sheet. The measurement scale used was in the form of continuous data with a measure of $0=$ less $($ score $<6) ; 1=\operatorname{good}($ score $\geq 6)$.

Operational definition of family support is a positive attitude from the family in the application of prenatal healthy behavior. Data collection was done using questionnaires. The measurement scale used is in the form of continuous data with a measurement of $\mathrm{O}=$ not supporting (negative); 1 = support (positive).

The operational definition of health personnel support is a positive attitude from health workers in the application of prenatal healthy behavior. Data collection was done using a questionnaire. The measurement scale used is in the form of continous data with the results of measuring $\mathrm{O}=$ not supporting (negative); $1=$ support (positive).

Operational definition of support from community leaders is a positive attitude from community leaders in the application of prenatal healthy behavior. Data collection was done using a questionnaire. The measurement scale used was in the form of continuous data with the results of measuring $\mathrm{O}=$ not supporting (negative); 1 $=$ support (positive).

Distance toposyandu is the ease of reaching the posyandu location or affordability of posyandu health service facilities. Data collection was done using questionnaire. Continuous data measurement scale was with $1(>1 \mathrm{~km})$ and $\mathrm{o}(<1 \mathrm{~km})$.

The operational definition of posyandu strata is a level that describes the quality, completeness and facilities of a posyandu.

\section{Study Instruments}

The instrument used in this study was a questionnaire in the form of questions and statements relating to healthy prenatal behavior and posyandu strata based on direct observation to posyandu officers.

\section{Data Analysis}

Univariate analysis was conducted to see the frequency distribution and characteristics of the research subjects. Bivariate analysis was carried out to study the relationship between prenatal healthy behavior and independent variables with chi-square test and calculation of odds ratio (OR) with a confidence level of CI of 95\%. Furthermore, multivariate analysis was performed using logistic regression using a multilevel approach.

\section{Research Ethics}

The study was carried out based on research ethics, included inform consent, anonymity, confidentiality, and ethical clearance. Ethical clearance in this study was obtained from the Faculty of Medicine, Universitas Sebelas Maret, Surakarta, Central Java.

\section{RESULTS}

\section{Sample Characteristics}

The results showed that most subjects were at the age of $>25$ years at $57.5 \%$. Table 1 showed sample characteristics.

\section{Table 1. Sample Characteristics}

\begin{tabular}{lcc}
\hline Age & n & \% \\
\hline$<25$ years & 95 & 47.5 \\
$\geq 25$ years & 115 & 57.5 \\
\hline
\end{tabular}

\section{Univariate Analysis}

Table 2 showed that mothers with higher education were 131 subjects (34.5\%), good maternal knowledge were 116 subjects (58\%), high family income were 128 subjects (64\%), positive family support were subjects (65.5), positive community leaders support were 102 subjects (51\%), positive health personnel support were 139 (69.5\%), and the long distance to health center were 88 subjects (44\%). 
Table 2. The Results of Univariate Analysis

\begin{tabular}{lcc}
\hline Variables & $\mathbf{n}$ & $\mathbf{\%}$ \\
\hline Maternal Education & 69 & 34.5 \\
Low & 131 & 65.5 \\
High & & \\
Knowledge & 84 & 42.0 \\
Poor & 116 & 58.0 \\
Good & & \\
Family Income & 72 & 36.0 \\
Low & 128 & 64.0 \\
High & & \\
Family Support & 69 & 34.5 \\
Negative & 131 & 65.5 \\
Positive & & \\
Support from Community Leaders & 98 & 49.0 \\
Negative & 102 & 51.0 \\
Positive & & \\
Health Personnel Support & 61 & 30.5 \\
Negative & 139 & 69.5 \\
Positive & & \\
Distance to Health Center & 112 & 56.0 \\
Easy to Access & 88 & 44.0 \\
Difficult to Access &
\end{tabular}

Table 3. Multivariate Analysis

\begin{tabular}{|c|c|c|c|c|}
\hline \multirow[b]{2}{*}{ Child Development } & \multirow[b]{2}{*}{ b } & \multicolumn{2}{|c|}{ CI $95 \%$} & \multirow[b]{2}{*}{$\mathbf{p}$} \\
\hline & & $\begin{array}{c}\text { Lower } \\
\text { Limit }\end{array}$ & $\begin{array}{l}\text { Upper } \\
\text { Limit }\end{array}$ & \\
\hline \multicolumn{5}{|l|}{ Fixed Effect } \\
\hline Maternal education $\geq$ senior high school & 4.64 & 2.05 & 7.23 & $<0.001$ \\
\hline High family income & 3.26 & 1.15 & $5 \cdot 37$ & 0.002 \\
\hline Good maternal knowledge & 2.83 & 0.90 & $4 \cdot 77$ & 0.004 \\
\hline Positive family support & 2.69 & 0.69 & 4.69 & 0.008 \\
\hline Strong community leader support & 3.01 & 1.05 & 4.96 & 0.003 \\
\hline Strong health personnel support & 3.74 & 1.44 & 6.04 & 0.001 \\
\hline Long distance to health center & -3.51 & $-5 \cdot 50$ & -1.52 & 0.001 \\
\hline \multicolumn{5}{|l|}{ Random Effect } \\
\hline \multicolumn{5}{|l|}{ Health Center } \\
\hline Var (constants) & 9.44 & 2.79 & 31.95 & \\
\hline $\mathrm{N}$ observation $=200$ & & & & \\
\hline Log likelihood $=-43.24$ & & & & \\
\hline ICC $=74.16 \%$ & & & & \\
\hline
\end{tabular}

\section{Multilevel Analysis}

Multivariate analysis used a multilevel logistic regression method and analyzed by using STATA 13. Multivariate analysis explained the effect of more than one independent variable on 1 dependent variable. Table 3 showed that there was a significant effect between maternal education, family income, family support, support from community leaders, health personnel support and distance to the health center. mothers with higher education were 131 subjects (34.5\%), good maternal knowledge were 116 subjects (58\%), high family income were 128 subjects (64\%), positive family support were subjects (65.5), positive community leaders support were 102 subjects (51\%), 
Journal of Maternal and Child Health, 2019, 4(4); 242-249

https://doi.org/10.26911/thejmch.2019.04.04.03

positive health personnel support were 139 (69.5\%), and the long distance to health center were 88 subjects (44\%).

\section{DISCUSSIONS}

1. The effect of maternal educational level on healthy prenatal behavior

The results of this study showed that there was an effect of maternal education on healthy behavior of prenatal mothers. This reinforced the opinion of Nureni (2012) who stated that education can improve health behavior and help to prevent a disease. The level of education influenced awareness of the importance of health for people and the environment which can encourage the need for health services.

\section{The effect of maternal knowledge} on healthy prenatal behavior

The results of this study showed that there was an effect of maternal knowledge on healthy behavior of prenatal mothers. Good maternal knowledge about healthy prenatal behaviorcould increase healthy behavior of prenatal mothers.

This was in line with a study done by Komariah (2008) which stated thatthe higher the respondent's knowledge, the higher the change in the respondent's healthy behavior. Without knowledge, there was no basis for making decisions and determining actions against the problems (Wibisono \& Dewi, 2009).

\section{The effect of family income on healthy prenatal behavior}

Family income can also affect someone in carrying out healthy behavior. The results of this study indicated that high family income would further support pregnant women to perform healthy behaviors. This was in line with the research conducted by Amalia (2009) which showed that healthy respondents were more likely to have high income compared to study subjects with low income.

\section{The effect of family support on healthy prenatal behavior}

The role of the family was needed to support the mothers to be more confident in conducting healthy behavior during pregnancy so that they can avoid complications during pregnancy and childbirth. The results of this study indicated that there was a significant influence between family support for prenatal healthy behavior. Positive family support can improve prenatal healthy behavior among mothers.This research was in line with the results of a study conducted by Tarigan in 2017 which stated that the support of both husband and parents' can influence the healthy behavior of pregnant women, one them was to support pregnant women to conduct antenatal care visits.

\section{The effect of community leader support on healthy prenatal behavior}

Community leaders also played an important role as one element of social capital that can affect prenatal mothers to behave in a healthy manner. In this study, there was a significant influence of the support of community leaders on the healthy behavior of pregnant women. The positive support from community leaders would increase the healthy behavior of prenatal mothers. Support from respected individuals was able to provide positive encouragement for participants, so that community leaders were believed to bring fighting spirit to the process of behavior change, especially maternal health behavior during pregnancy. (Heaney \& Israel, 2008).

\section{The effect of health personnel sup- port on healthy prenatal behavior}

Health personnel was an important need to know the condition of pregnancy. The results of this study indicated that there was an effect of the support of health personnel on prenatal healthy behavior 
among mothers. The positive support provided by health personnel can help pregnant women in conducting healthy behaviors. Fitrayeni (2015) in her research also suggested that the support of health personnel played an important role in changing the behavior of pregnant women. Health personnel who provide good support for pregnant women can improve the healthy behavior of pregnant women.

\section{The effect of distance to health cen- ter on healthy prenatal behavior}

In this study, there was a significant effect between distance to the health center and the healthy behavior of pregnant women. Health service places that were difficult to reach can reduce the healthy behavior of pregnant women. This reinforced the theory of Anderson (1998) in Pekabanda (2016) which stated that one of the inhibiting factors in doing healthy behavior was the difficulty in reaching health services.

\section{The effect of health center strata on child development}

In this study, there was a significant relationship between the health center strata and prenatal healthy behavior. Health center was useful for empowering the community and providing convenience to the community in obtaining basic health services, especially to conduct healthy behavior during pregnancy so as to accelerate the decline in maternal and infant mortality. It can be carried out at hamlet halls, sub-district halls, or other places that were easily accessible to the community (Ismawati, 2010). If the health center activities were well organized, they would make a great contribution in reducing maternal, infant and toddlers mortality (Department of Health, 2012).

Based on the results of the study, it can be concluded that maternal education, family income, maternal knowledge, family support, community leaders' support, health personnel support, and distance to the health center have a statistically significant effect on prenatal healthy behavior. Variations at the health center level showed a contextual effect on prenatal mothers' healthy behavior.

\section{REFERENCES \\ Agustina, Nora (2018). Perkembangan Pe- serta Didik. Yogyakarta: Deepublish. \\ Alomar MJ (2014). Factors affecting the development of adverse drug react- ions (Review article). Saudi Pharma- ceutical Journal, 22(2), 83-94. https:- //doi.org/10.1016/j.jsps.2013.02.003. \\ Catalano PM, Shankar K (2017). Obesity and pregnancy: Mechanism of short term and long term adverse conse- quences for mother and child. BMJ, 356. https://doi.org/10.1136/BMJ.jl. \\ Cetin I, Alvino G (2009). Intrauterine growth restriction: Implications for placental metabolism and transport. A Review. Placenta, 23, 77-82. https:- //doi.org/10.1016/j.placenta.2008.12. oo6.}

Cetin I, Berti C, Calabrese S (2010). Role of micronutrients in the periconceptional period. Human Reproduction Update, 16 (1), 80-95. https://doi.org/10.1093/humupd/dmpo25.

Cohen BE, Durstenfeld A, Roehm PC (2014). Viral causes of hearing loss: A review for hearing health professionals. Trends in Hearing, 18, 1-17. https://doi.org/10.1177/23312165145 41361.

Desmita (2013). Psikologi Perkembangan. Bandung: PT Remaja Rosdakarya.

Ehrenstein V, Pedersen L, Grijota M, Nielsen GL, Rothman KJ, Sorensen HT (2009). Association of apgar score at five minutes with long-term neurologic disability and cognitive function in a prevalence study of Danish Con- 
scripts. BMC Pregnancy and Childbirth, 9(1). https://doi.org/10.1186/1471-2393-9-14.

Han Z, Mulla S, Beyene J, Liao G, McDonald SD (2011). Maternal underweight and the risk of preterm birth and low birth weight: A systematic review and meta-analyses. International Journal of Epidemiology, (40), 65-101. https://doi.org/10.1093/ije/dyq195.

Hurlock, Elizabeth B (2013). Perkembangan Anak, Edisi keenam. Jakarta: Erlangga.

Irianto K (2014). Biologi Reproduksi. Bandung: Alfabeta.

Kementerian Kesehatan Republik Indonesia. (2011). Profil Kesehatan Indonesia 2010. Jakarta: Kementerian Kesehatan Republik Indonesia. http://www.depkes.go.id/resources/downl oad/pusdatin/profil-kesehatan-indonesia/profil-kesehatan-indonesia-2010.pdf.

Leveno, Kenneth J (2009). Obstetri Williams: Panduan Ringkas. Ed. 21. Jakarta: EGC.

Littletan LY, Engebretson J (2012). Maternal, neonatal, and women's health nursing. New York: Delmar Cengage Learning. Page 878.

Luyckx VA, Brenner BM (2015). Birth weight, malnutrition and kidney-associated outcomes-a global concern. Nature Reviews Nephrology, 11(3), 135-149. https://doi.org/10.1038/nrneph.2014.251.

Menezes PR, Lewis G, Rasmussen F, Zammit S, Sipos A, Harrison GL, Tynelius P, Gunnel D (2010). Paternal and maternal ages at conception and risk of bipolar affective disorder in their offspring. Psychological Medicine, 40 (03): 477. https://doi.org/10.1017/s003329170999064x.
Murti B (2013). Desain dan ukuran sampel untuk penelitian kuantitatif dan kualitatif di bidang kesehatan. Yogyakarta: Gadjah Mada University Press.

Papalia DE, Olds SW, Feldman RD (2009). Human Development (Perkembangan Manusia edisi 10 Buku 2). (Penerj. Brian Marwensdy). Jakarta: Salemba Humanika.

Papalia DE, Feldman RD (2014). Menyelami perkembangan manusia; Experience Human Development.Jakarta: Salemba Humanika.

Parsa P, Besharati F, Maghsodi SH, Afshari M, Emdadi S (2018). Factors influencing the behavior of pregnant women towards using prenatal care services in Iranian Healthcare Center. Journal of Midwifery and Reproductive Health, 6 (1), 1141-1148. https://doi.org/10.22038/jmrh.2017.9972.

Purwoastuti E, Walyani ES (2015). Perilaku \& softskills kesehatan. Yogyakarta: Pustaka Baru Press.

Profil Dinas Kesehatan Kabupaten Bengkayang (2015). Profil Kesehatan Kabupaten Bengkayang Tahun 2015. Bengkayang: Profil Dinas Kesehatan Kabupaten Bengkayang.

Profil Kesehatan Provinsi Kalimantan Barat (2015). Buku Profil Kesehatan Provinsi Kalimantan Barat Tahun 2015. Pontianak: Profil Kesehatan Provinsi Kalimantan Barat.

Proverawati A (2011). Anemia dan Anemia Kehamilan. Yogyakarta: Nuha Medika Rahman MM, Abe SK, Rahman MS, Kanda, M, Narita S, Bilano V, Ota E, Gilmour S, Shibuya K (2016). Maternal anemia and risk of adverse birth and health outcomesin low- and middle-income countries: Systematic Review and Meta-Analysis. American Journal of Clinical Nutrion, 103, 485-504. https://doi.org/10.3945/ajen.115.107896. 
Sadler TW (2012). Langmans's Medical Embryology, 12thEd. Philadelphia: Lippincot Williams \& Wilkins.

Samsunuwiyati M (2013). Psikologi perkembangan. Bandung: PT Remaja Rosdakarya.

Santrock JW (2011). Masa perkembangan anak. (Terjemahan Verawaty Pakpahan). New York: McGraw-Hill.

Sudargo T, Aristasari T, Afifah A (2018). 1.00o hari pertama kehidupan. Yogyakarta: Gadjah Mada University Press. ISBN: 978-602-386-233-7.

Sudirjo E, Alif MN (2018). Pertumbuhan dan perkembangan motorik. Jawa Barat: UPI Sumedang Press. ISBN: 978-602-643821-8.

Washio Y, Humphreys M (2018). Maternal behavioral health: fertile ground for behavior analysis. Journal of Associa- tion for Behavior Analysis International. https://doi.org/10.1007/s40614-018-0143-z.

Wawan (2011). Teori dan pengukuran pengetahuan, sikap dan perilaku manusia. Yogyakarta: Nuha Medika.

Weir Z, Bush J, Robson SC, McParlin C, Rankin J, Bell R (2010). Physical activity in pregnancy: A qualitative study of the beliefs of overweight and obese pregnant women. BMC Pregnancy and Childbirth. https://doi.org/10.1186/1471-2393-10-18.

WHO NCD Alliance (2011). NCD Alliance Annual Report 2009 - 2011. United Nation: NCD Alliance. https://ncdalliance.org/resources/ncd-allianceannual-report-2009-2011 